\title{
KRIYA TEKSTIL TIE-DYE (IKAT CELUP): SEBUAH MEDIA EKSPLORASI ESTETIS YANG POPULER
}

\author{
Suryo Tri Widodo *)
}

\begin{abstract}
Tie-dye becomes the one of the most popular craft textile, which is known almost all over the world including in Indonesia. Making motif on to the fabric using tie-dye techniques is very easy to be learned, beside there are many kind of simple technics on it. These techniques are very unique and could be developed and explored without limited. The unpredictable effects of motifs sometimes may appear and can be resulted from tie-dye techniques.

In this article we will study about tie-dye in many aspect i.e. term of tie-dye, tradition and culture background of tie-dye, mainly showing about tie-dye techniques, and a few tie-dye products. This paper expected give the wide describing and inspiring about tie-dye in craft textile works or tiedye as an expression of fine art.
\end{abstract}

Keywords: tie-dye, resist-dye, textile motif, craft textile, aesthetic exploration

\section{Pendahuluan}

Tie-dye merupakan salah satu produk budaya dan tradisi dalam pembuatan motif di atas kain yang dikenal cukup luas tidak hanya di Indonesia saja, melainkan juga di hampir seluruh penjuru dunia. Istilah tie-dye apabila diterjemahkan secara sederhana sebagai leksikon ke dalam bahasa Indonesia artinya adalah 'ikat celup'. Tie-dye mengandung pengertian bahwa dalam proses pembuatan motif di atas kain dipergunakan istilah ikat sebagai proses merintangi atau menahan warna, sedangkan istilah celup diartikan sebagai proses pemberian warna. Di Indonesia sendiri, tie-dye merupakan salah satu jenis kain tradisional yang dikenal sarat dengan berbagai muatan, baik dari aspek estetis, simbolis, maupun fungsinya.
Keunikan dari teknik tie-dye terletak pada efek motif yang dihasilkannya, kadangkadang muncul berbagai macam efek mengejutkan secara tak terduga. Seringkali efek tersebut tidak bisa diwujudkan atau diulangi lagi untuk menghasilkan efek yang mutlak sama secara persis, walaupun diterapkan teknik atau metode yang sama. Salah satu kelebihannya terletak pada proses pembuatan yang cukup sederhana, dapat menghasilkan motif di atas kain secara cepat dan mudah, dapat dipelajari dalam waktu yang relatif singkat, serta lebih mudah dipelajari dari pada batik. Motif-motif yang dihasilkan melalui teknik ini memiliki nilai artistik yang cukup tinggi, sehingga berpotensi sebagai media ekspresi dalam berkarya seni rupa, dikarenakan unsur eksperimen atau uji coba sangat dimungkinkan di dalamnya. Tie-

\footnotetext{
* Suryo Tri Widodo (suryotw@gmail.com), Staf Pengajar Program Studi Kriya Seni, Jurusan Kriya, Fakultas Seni Rupa, Institut Seni Indonesia Yogyakarta
} 
dye mengalami pengembangan yang cukup baik dalam dunia kriya tekstil secara umum. Berbagai keteknikan dalam tie-dye selalu berkembang dan dapat dieksplorasi secara terus-menerus tanpa dibatasi oleh keteknikan yang sudah ada dan lazim dipergunakan sebelumnya, termasuk dari aspek alat dan bahan yang dipergunakan.

Dalam artikel kali ini, penulis mencoba memberikan gambaran mengenai seluk-beluk tie-dye sebagai salah satu keteknikan dalam kriya tekstil. Pembahasan diarahkan untuk menguraikan dan menelaah berbagai peluang dan potensi dalam rangka pengembangannya secara lebih lanjut. Sekelumit definisi mengenai tie-dye akan menjadi ulasan pertama, dilanjutkan dengan budaya dan tradisi tie-dye dari berbagai negara sebagai topik pembahasan kedua. Pada pembahasan ketiga, penulis akan memaparkan beberapa keteknikan dasar yang lazim dipergunakan dalam tie-dye. Beberapa contoh produk yang dapat dihasilkan melalui media tie-dye juga akan disajikan. Tulisan ini diakhiri dengan penutup sebagai simpulan dari seluruh pembahasan.

\section{Definisi Tie-dye}

Dalam The Modern Textile Dictionary, tie-dye dipahami sebagai metode pencelupan yang menghasilkan rancangan di atas kain dengan cara kain dikumpulkan dan diikat kencang dengan serat, tali, atau benang, kemudian kain dicelup atau diwarna. Pada area yang dikumpulkan atau diikat tersebut tertahan dari perembesan warna dalam proses pencelupan hingga menghasilkan efek titik-titik atau garis-garis yang tak beraturan dalam latar belakang pencelupan (Linton, 1954: 618). lla Keller dalam bukunya Batik The Art and Craft berpendapat, tie-dye bukanlah batik yang memerlukan pelilinan (nonwax), namun dalam proses pewarnaannya sama, yaitu dimulai dari warna yang paling muda atau terang pada pencelupan pertama (Keller, 1971: 56). Lebih lanjut dipertegas oleh Joanifer Gibbs, bahwa tie-dye adalah hasil kerja dari pelbagai metode lipat-melipat bersama dengan teknik ikatan atau pertalian sebagai bentuk penahanan terhadap warna (Gibbs, 1974: 8). Menurut Sumarmi Arimbi seorang perancang dan pengusaha tie-dye di Yogyakarta mengemukakan bahwa tie-dye merupakan salah satu cara untuk membuat motif dengan jalan ikat dan celup (tie and dye), namun di samping itu ada cara lain, yaitu dengan cara jahit, ikat, kemudian celup, dan masih bisa dikembangkan lagi tekniknya dengan berbagai macam cara dan sarana (Widodo, 1997).

Dari beberapa deskripsi di atas, dapat ditarik suatu pemahaman yang utuh, bahwa tie-dye adalah istilah untuk menyebut sebuah metode dalam pembuatan motif di atas kain dengan cara tie (ikat), yang dipahami berfungsi sebagai penahan warna (resist dye) untuk menghasilkan atau membentuk motif di atas kain, sedangkan dye (celup) merupakan proses pewarnaan yang memunculkan motif pada area yang tidak diikat. Pada tahap perkembangan selanjutnya, tie-dye menjadi sebuah istilah umum sebagai teknik atau metode dalam membuat motif di atas kain, yang tidak dibatasi dengan cara ikat dan celup saja, melainkan juga dipakai sebagai istilah untuk menyebut teknik lain serupa, seperti pleat (lipat), roll (gulung), stitch (jahit), kerut, dan lain sebagainya, yang kesemuanya itu dapat dikategorikan sebagai bagian dalam keteknikan tie-dye.

\section{Budaya dan Tradisi Tie-dye}

Hingga saat ini belum diketahui secara pasti kapan asal-mula dan dari mana asal-usul 
tie-dye. Tie-dye menjadi salah satu hasil karya seni yang banyak mengalami sentuhan dan pengaruh dari beragam budaya yang telah ada sebelumnya. Dalam proses perkembangannya, tie-dye tidak berdiri sendiri, sehingga bisa dikategorikan sebagai sebuah produk multikultural. Tie-dye menjadi sebuah hasil budaya manusia yang lahir seiring dengan kemajuan pola pikir manusia itu sendiri. Budaya pembuatan motif di atas kain melalui teknik ini diperkirakan ditemukan setelah manusia mengenal budaya menenun yang menghasilkan tekstil sebagai bahan baku utama dalam pembuatan sandang, menggeser penggunaan bahan dari tumbuhan, kulit kayu, maupun kulit binatang.

Apabila ditinjau dari aspek secara teknis, tie-dye merupakan sebuah kebudayaan alami dan bisa dikatakan menjadi budaya asli dari masing-masing daerah penghasilnya. Hal ini dikarenakan keteknikannya tidak dapat diusut asal-usulnya hanya pada satu tempat saja yang dianggap istimewa. Sebagai contoh, tie-dye sudah ada dan dikenal di China selama masa Dinasti T'ang (618-906 M) dan di Jepang pada masa Periode Nara (552-794 M). Tie-dye juga menjadi sebuah tradisi dari penduduk asli yang sudah dikenal selama berabad-abad di Asia Tenggara, Indonesia, India, di sebagian negara Afrika, serta negara-negara lain (Anderson, 1974: 7).

Tie-dye disebarkan ke beberapa daerah di Indonesia oleh para pedagang, kemungkinan oleh orang-orang India dan Arab muslim yang memperkenalkan teknik tenun ikat, sehingga diprediksi tie-dye dan tenun ikat merupakan dua keteknikan yang tergabung dalam periode yang sama. Tie-dye menjadi sebuah keteknikan yang acapkali dipergunakan di India seperti halnya teknik dalam tenun ikat. Daerah di Indonesia yang cukup dikenal sebagai penghasil tie-dye adalah di Jawa (Gresik di Jawa Timur, Yogyakarta,
Solo, dan Jawa Tengah), kemudian di Sulawesi, Sumatera Selatan khususnya di daerah Palembang, Kalimantan, Bali, serta Lombok yang juga sangat dikenal sebagai daerah penghasil tenun ikat (Warming and Gaworski, t.t.: 122).

Di Indonesia, keteknikan dalam tie-dye bukan merupakan pokok dari perbedaan yang berarti antardaerah penghasilnya, sehingga ada berbagai kemiripan yang dapat dijumpai. Gambaran ini terlihat di Jawa yang dikenal dengan istilah pelangi, jumputan, dan tritik. Pelangi menjadi nama yang lazim untuk menunjukkan spesifikasi dari pelbagai keteknikan (mix technics) dalam tie-dye, di samping juga untuk menyebut kain tie-dye yang memiliki ciri dalam tata warna gradasi dan kaya warna (multicoloured). Jumputan juga menjadi istilah yang populer untuk menyebut kain tie-dye di Jawa, karena di dalam perwujudannya dilakukan dengan teknik menjumput atau mencubit kain. Tritik dari kata tarik (bahasa Jawa), yaitu merupakan keteknikan jahit (stitch) dengan mempergunakan teknik jahit jelujur yang dieratkan atau dikuatkan. Dalam keteknikan tritik ini bisa dihasilkan motif berupa garis atau lajur sesuai garis rancangan. Benang yang dipergunakan dalam keteknikan ini merupakan benang sintetis yang kuat atau dahulu biasa digunakan serat yang kuat seperti serat nanas. Cara menjahitnya dengan jarak yang pendek antartitik jahitan (short stitches), kemudian benang ditarik dan dikumpulkan dengan kuat untuk tiap beberapa $\mathrm{cm}$ jarak jahitan, kemudian dikunci dengan jalan diikat kuat-kuat namun benang jangan sampai terputus, baru dilakukan proses pewarnaan (Warming and Gaworski, t.t.: 122).

Di Jawa Tengah, tradisi dalam pembuatan kain tie-dye merupakan sebuah keahlian rakyat yang bersifat turun-temurun yang dipergunakan untuk mendekorasi atau 
menghiasi banyak aksesoris. Lazimnya, teknik tie-dye dikombinasikan dengan batik, dalam bentuk udheng (ikat kepala), kemben, dodot, dan kelambu untuk kamar tidur raja. Macammacam tritik di Jawa dikenal dengan nama untu walang yang dipakai untuk kain gula klapa dengan warna merah dan putih, kain sindur, kemben dan lain sebagainya. Motif tritik yang lain dikenal antara lain, seperti tapak dara, regulon, dan gadan (Djoemena, 1990: 8).

Kain-kain tie-dye di Jawa umumnya dipergunakan dalam berbagai macam ritual adat seperti dalam upacara perkawinan yang melambangkan kesuburan dan kemakmuran. Kain tie-dye yang dipakai sebagai pembungkus pusaka disebut klabang ngantup. Dalam bentuk kain dodot, tie-dye biasanya dikombinasikan dengan teknik batik sebagai perlengkapan busana raja yang disebut dengan dodot bango tulak, dengan ciri khas warna biru tua atau hitam dan putih. Ada sebagian kepercayaan di masyarakat untuk meletakkan kain bango tulak ini di bawah bantal, dengan tujuan agar terhindar dari halhal yang tidak diinginkan selama tertidur lelap. Kain bango tulak juga ada yang diikatkan pada tiang penyangga rumah atau soko guru, sebagai tolak bala agar rumah beserta penghuninya terhindar dari segala macam marabahaya.

Di Kalimantan sejak abad ke-12 hingga abad ke-14, dikenal suatu kain tie-dye dengan nama calapan yang berasal dari kata celupan dengan warna kuning sebagai warna sakral. Kain calapan juga difungsikan dalam berbagai ritual adat atau keagamaan, di samping dipergunakan oleh kalangan bangsawan pada upacara tertentu seperti perkawinan, badudus (mandi pengantin), ma-ayun anak (upacara untuk bayi berumur 40 hari), dan potong rambut. Pemakaian kain calapan dipercaya berfungsi untuk mengobati berbagai macam penyakit atau tolak bala yang biasa disebut kain pamintan (dari kata permintaan) karena kain ini didapat dari hasil permintaan seseorang untuk keperluan-keperluan khusus. Motif-motif dari kain calapan mengandung makna, termasuk fungsinya dalam upacara untuk tujuan tertentu pula. Kepercayaan ini masih hidup hingga kini, terbukti dengan masih seringnya kain tersebut dipergunakan. Kain ini dapat berupa laung (ikat kepala), kahamban (kerudung), udak (kemben), dan tapih (Djoemena, 1990: 98-99). Umumnya kain tie-dye di Kalimantan kaya akan motif, dibuat dengan teknik stitch (jahit) yang dikenal dengan nama sasirangan. Adapun nama motifnya adalah bintang bahambur, awan bairing, iris pudak, ombak sinapur karang, kangkung kaombakan, bayam raja, dan turun dayang. Untuk teknik pewarnaan tidak hanya terbatas dengan teknik dye (celup) saja, melainkan ada yang disiramkan sesuai bidang motifnya masing-masing, karena biasanya dalam sebuah kain terdapat bermacam-macam motif dan warna yang beraneka ragam (Djoemena, 1990: 98-101).

Di Sulawesi Selatan tepatnya di daerah Rongkong Toraja terdapat kain tie-dye yang dikenal dengan nama roto dengan ukuran motif terbatas menurut jenisnya. Kain ini menggambarkan matahari dan tata surya sebagai perlambang kehidupan. Sementara di Bali, kain bermotif tie-dye memiliki perpaduan aneka ragam warna dan corak yang tampak dalam berbagai ritual, misalnya upacara potong gigi, ngaben (pembakaran mayat), untuk hiasan, dan panji-panji (Djoemena, 1990: 96).

Di Jepang, tie-dye dikenal dengan istilah shibori yang berarti suatu variasi atau cara dalam menghiasi permukaan tekstil dengan cara dikuatkan sebelum diwarna. Shibori berasal dari kata shiboru yang berarti berakar, menjepit, dieratkan, dan ditekan. 
Kata "berakar" ditekankan pada cara pengerjaan kain yang indah, seperti permukaan dua dimensi dan bentuk dengan kesan tiga dimensi lipatan yang dikuatkan, dijahit, ditarik, dan dibelit dengan tali, sesuai lajur pola yang dikunci. Shibori dikenal sebagai metode melipat tekstil dengan berbagai kemungkinan untuk dikreasikan lagi. Banyak istilah dalam tie-dye yang menurut pengertian Jepang adalah shibori, sudah dikenal di seluruh pelosok dunia. Rumpun-rumpun dalam shibori juga dipergunakan dalam istilah bahasa Inggris karena hampir tidak ada padanan katanya. Faktanya, banyak bahasa yang tidak memiliki istilah yang meliputi semua variasi keteknikan dalam shibori. Terdapat tiga istilah untuk memilah metode dalam teknik shibori yang diadopsi dari istilah umum yang dikenal secara internasional, yaitu pelangi (istilah dari Melayu/Indonesia), yakni proses menguatkan dan mengikat kain, kemudian bandha (istilah dari India) untuk proses yang sama, dan tritik salah satu istilah dari Jawa untuk istilah "tarik" dan menolak zat warna. Ketiga istilah tersebut hanya menggambarkan sebagian dari berbagai macam keteknikan dalam shibori.

Sejarah shibori diawali dengan kemajuan dunia pertekstilan pada abad ke-16, merupakan masa pergolakan kelompok kelas bawah yang berpengaruh terhadap perkembangan mode pakaian kelas atas menjadi lebih sederhana. Pakaian lapisan dalam kimono berubah menjadi pakaian luar yang dipakai orang kebanyakan. Shibori di daerah-daerah lokal, referensi pertama adalah tentang daerah-daerah yang memproduksi shibori untuk pertama kalinya. Dalam antologi Haikukeikokigusa (1638), dua tempat yang disebut adalah Bungo (daerah administrasi kota) dan Takashi di daerah administrasi Kumamoto. Bungo shibori terkenal khususnya di awal masa Edo. Hal ini termuat dalam
Koshono Nidai Otoko (1984) yang ditulis oleh Ihara Saikaku dalam buku travel dan di catatan pusat produksi lokal, termasuk dalam catatan Ukyu-e oleh Utagawa.

Awalnya katun shibori dari Bungo dibuat dan dipergunakan orang kebanyakan. Shuruki sebagai pusat produksi shibori menjadi pelabuhan penting di bagian wilayah barat Kyoso sebagai pusat transportasi. Daerah ini menjadi ramai karena banyak pedagang dan wisatawan yang datang dari Kyoto dan Osaka, serta para bangsawan feodal dari Kyusu dalam kunjungannya ke pusat kota Edo. Berbagai produk shibori dari Bungo dijual sebagai cenderamata berupa saputangan, scarf, stola (selendang panjang), kipas dengan sedikit motif, dan sebagainya. Shuruki shibori merupakan contoh dari proses ini. Cenderamata bungo shibori diyakini telah mulai dibuat di Oari (Nagoya) sekitar tahun 1610 ketika istana Nagoya didirikan.

Salah satu teknik utama di Arimatsu dan Narumi adalah miura shibori (diambil dari nama orang yang memperkenalkan shibori di daerah itu). Selama 380 tahun, Arimatsu dan Narumi kota tetangga Nagoya merupakan dua daerah utama penghasil shibori di Jepang hingga kini. Dua kota itu memiliki posisi strategis karena berada di sepanjang jalan Tokaido. Pencelupan di daerah shibori. Setelah dipromosikan dan dilindungi oleh keluarga Arimatsu dan Narumi mengembangkan teknik pencelupan di daerah mereka, sehingga ada salah seorang yang bernama Biokambunki menggambarkan jatuh bangunnya tempat penghasil shibori. Ketika ia melewati Arimatsu pada tahun 1696, di sana hanya sedikit toko shibori. Selang 50 tahun kemudian kota ini sudah penuh dengan toko shibori, dan reputasinya tersebar luas di seluruh Jepang. Akan tetapi setelah itu tidak terdengar lagi tentang bungo Tokugawa dari Oari, teknik shibori dari Arimatsu dan Narumi mengalami 
banyak pengembangan yang bersifat kreatif dan menghasilkan shibori yang lebih indah. Akan tetapi lama-kelaman kedua kota ini kehabisan tenaga pencelup, sehingga akhirnya monopoli produk shibori mereka terhapus di akhir masa Edo. Hal ini terutama dipicu oleh faktor keberadaan tenaga pencelup dari kedua kota tersebut yang berpindah ke daerah atau kota lain. Pada awal masa Meiji, produksi katun telah tersebar di seluruh wilayah Jepang. Hal ini menjadi faktor punahnya produksi shibori indigo (warna biru alami), dikarenakan juga telah ditemukan bahan warna kimia di akhir masa Meiji.

Runtuhnya era shibori adalah sejak dikeluarkannya peraturan baru dalam dunia pertekstilan setelah Perang Dunia I. Saat ini daerah yang masih memproduksi shibori adalah Kyoto dan Nagoya. Dikarenakan metode pencelupan tradisional ini menghabiskan waktu dan tenaga yang tidak efisien, penerus produksi shibori ini pun berangsur-angsur mulai berkurang. Di masa lalu, pusat produksi ini bergantung pada warisan teknik tradisional dengan menghidupkan metode-metode yang telah punah, sehingga untuk meneruskan dan mengembangkan tradisi ini diperlukan usaha yang sungguh-sungguh.

Hingga kini kegunaan shibori selain sebagai cenderamata dan barang-barang rumah tangga juga sebagai kimono. Dahulu pemakaian bagi masyarakat golongan menengah ke bawah dipergunakan bahan katun, sedang yang terbuat dari sutera dikenakan oleh kalangan bangsawan. Untuk warna juga diatur, untuk golongan menengah ke bawah hanya diperkenankan mempergunakan warna indigo. Motif-motif yang diambil kebanyakan berasal dari alam lingkungan seperti bentuk batu-batuan, flora, dan fauna. Pengambilan nama motif bersumber dari nama pembuatnya, dari segi teknik, ada yang diambil dari efek munculnya motif, adapula yang diambil dari nama daerah shibori tersebut diproduksi. Nama-nama motif yang cukup dikenal, di antaranya adalah kiko shibori, komatsu, arimatsu, kanoko, tesuji, arashi shibori, dan lain-lain (Wada, Rice, and Barton, 1999; Widodo,1998).

Di India, tie-dye dikenal dengan istilah bandha atau bandhana (bahasa. Inggris bind yang artinya mengikat), dikenal juga dengan istilah chundri (Robinson, 1969: 78). Bandhana banyak dijumpai di daerah perkampungan yang memproduksinya dengan harga yang relatif murah. Warna, motif, dan bahan sangat bervariasi, karena berfungsi sebagai kain sari untuk pakaian dan kerudung oleh orang-orang Hindu maupun muslim, dengan bahan warna alami maupun sintetis. Bahan-bahan tipis terbuat dari polyester banyak dijumpai dengan warna gradasi maupun kontras. Museummuseum di India banyak tersimpan motif bandha yang kecil dan rumit dengan motif flora maupun fauna. Untuk motif fauna biasanya berupa binatang, seperti gajah, dan kijang. Pembentukan motif dilakukan dengan teknik tie (ikat) dengan ikatan yang kecil nan halus. Umumnya dipergunakan kain yang tipis dengan tenunan renggang, sehingga teknik stitch (jahit) tidak banyak dijumpai, karena kurang cocok untuk diterapkan (Widodo,1998).

Tie-dye begitu dikenal di hampir seluruh penjuru dunia. Keteknikan ini seolaholah hampir tak ada matinya. Motif ikat dan warna-warna cerah seperti pelangi untuk pakaian selalu up to date dan menjadi populer kembali. Mengadopsi teknik celup dan ikat, produsen mengeluarkan model uniseks untuk pembeli individual atau pasangan dengan motif bunga, hati, mata, matahari, pelangi, daun ganja, atau simbol damai dengan harga terjangkau. Di Amerika Serikat, tie-dye juga dilekatkan pada baju bayi, tas tangan, bed 
cover, handuk, hingga sepatu. Tie-dye juga sangat populer di AS pada akhir 1960-an sampai awal 1970-an sebagai bagian dari gaya hidup hippie dan kebudayaan tandingan (counter-culture). Musisi, penyanyi, dan grup band, seperti Grateful Dead, The Rolling Stones, Janis Joplin, dan John Sebastian, menjadi simbol dan penyebar gaya hidup generasi. Situs Time Magazine menyebut warna dan motif tie-dye adalah simbol gaya psychedelic yang kental dengan aroma mariyuana. Burlington Industries, raksasa tekstil di AS, lantas memproduksi massal mode ini (KOMPAS, 2009: 27).

Selain dari berbagai daerah di Indonesia dan beberapa negara tersebut di atas, berikut disajikan sekilas gambaran umum tentang tie-dye di beberapa negara lain melalui tabel di bawah ini (Robinson,1969: 85).

\begin{tabular}{|c|c|c|c|}
\hline Negara & Daerah/Suku & Bahan Dasar & Keterangan \\
\hline Algeria & - & Wool & $\begin{array}{l}\text { Satu warna, desain menyebar tidak beraturan, } \\
\text { kadang berkelompok. }\end{array}$ \\
\hline Tunisia & Gabes & Wool & $\begin{array}{l}\text { Berbentuk bulatan-bulatan tidak beraturan dengan } \\
\text { satu warna. }\end{array}$ \\
\hline Tripolitania & - & Wool & $\begin{array}{l}\text { Polanya dengan satu warna, yang dihasilkan } \\
\text { dengan menjahitkan/menempelkan pernak- } \\
\text { pernik/hiasan. }\end{array}$ \\
\hline Mesir & Luxor & Wool & Tidak tentu. \\
\hline $\begin{array}{l}\text { French } \\
\text { Sudan }\end{array}$ & $\begin{array}{l}\text { Bambara } \\
\text { Mande } \\
\text { Soninke }\end{array}$ & Katun & $\begin{array}{l}\text { Satu warna, kebanyakan dengan warna dasar biru, } \\
\text { hiasan - hiasannya dalam berbagai ukuran, juga } \\
\text { berukuran besar dan kadang dikombinasikan } \\
\text { dengan lipatan, jelujuran / jahitan atau metode } \\
\text { pembungkusan dengan ditahan/diikat. }\end{array}$ \\
\hline Gambia & - & Katun & - \\
\hline Sierra Leone & Mendi & Katun & $\begin{array}{l}\text { Dikombinasikan dengan lipatan dan rempel } \\
\text { (jelujuran yang ditahan/ditarik), satu warna, yaitu } \\
\text { biru. }\end{array}$ \\
\hline Liberia & $\begin{array}{l}\text { Vei } \\
\text { Kru }\end{array}$ & Katun & Kebanyakan satu warna, yaitu celupan warna nila. \\
\hline Ivory Coast & $\begin{array}{l}\text { Baule } \\
\text { Diula }\end{array}$ & Bast, katun & $\begin{array}{l}\text { Pada bast, polanya dengan dua warna; pada kain } \\
\text { katun dengan satu warna putih atau merah pada } \\
\text { dasar warna nila. Pada beberapa cadangan yang } \\
\text { berukuran besar kadang dikombinasikan dengan } \\
\text { lipatan atau rempel (jahitan yang ditarik/ditahan). }\end{array}$ \\
\hline Gold Coast & - & Katun & - \\
\hline Dahomey & - & - & - \\
\hline Nigeria & Ashanti & Katun & $\begin{array}{l}\text { Cadangan dihasilkan dengan menyambung kerikil- } \\
\text { kerikil, kadang dikombinasikan dengan teknik } \\
\text { rempel (jahitan yang ditarik/ditahan); satu warna }\end{array}$ \\
\hline
\end{tabular}




\begin{tabular}{|c|c|c|c|}
\hline & $\begin{array}{l}\text { Daerah Cross } \\
\text { River } \\
\text { Lagos (Yoruba) }\end{array}$ & $\begin{array}{l}\text { Katun } \\
\text { Katun }\end{array}$ & $\begin{array}{l}\text { (dasar biru). } \\
- \\
\text { Satu warna (kebanyakan dengan dasar biru). }\end{array}$ \\
\hline Kamerun & $\begin{array}{l}\text { Grasslands } \\
\text { (Bamum) }\end{array}$ & $\begin{array}{l}\text { Kain dari } \\
\text { kulit kayu }\end{array}$ & $\begin{array}{l}\text { Satu warna (celupan lumpur), desainnya sederhana } \\
\text { motif menyebar. }\end{array}$ \\
\hline $\begin{array}{l}\text { Belgian } \\
\text { Congo }\end{array}$ & Bakuba & $\begin{array}{l}\text { Susunan } \\
\text { Raffia }\end{array}$ & $\begin{array}{l}\text { Satu warna (dasarnya warna merah); } \\
\text { cadangannya/hiasannya dikelompokkan dalam } \\
\text { formasi /susunan seperti berlian/intan. }\end{array}$ \\
\hline Zanzibar & - & Katun & Import dari Pakistan atau India \\
\hline $\begin{array}{l}\text { Amerika } \\
\text { Serikat }\end{array}$ & $\begin{array}{l}\text { Utha, Arizona, } \\
\text { New Mexico } \\
\text { (Peublo) }\end{array}$ & Katun & $\begin{array}{l}\text { Pre-Columbian; satu warna. Lingkaran atau persegi } \\
\text { empat yang diulang-ulang seperti pola yang } \\
\text { sederhana. Peninggalan/sisanya saat ini kadang- } \\
\text { kadang dalam bentuk sangat primitif. }\end{array}$ \\
\hline Mexico & $\begin{array}{l}\text { Hidalgo, } \\
\text { Mahinalco, } \\
\text { Otomi, Peublo, } \\
\text { Tehuantepec, } \\
\text { Veracruz, } \\
\text { Zocatican }\end{array}$ & $\begin{array}{l}\text { Wool, } \\
\text { katun }\end{array}$ & $\begin{array}{l}\text { Satu warna, biasanya menggunakan permainan } \\
\text { tambahan (corak) dengan teknik stitch (jahit). }\end{array}$ \\
\hline Guatemala & $\begin{array}{l}\text { Region of } \\
\text { Quetzaltenango }\end{array}$ & Katun & - \\
\hline Peru & - & Katun & $\begin{array}{l}\text { Pola Pre-Columbian dengan satu warna yang } \\
\text { berurutan/ berderetan. Sisa-sisanya/ } \\
\text { peninggalannya jarang. }\end{array}$ \\
\hline Bolivia & - & - & Tidak tentu. \\
\hline Paraguay & $\begin{array}{l}\text { Gran Chaco } \\
\text { (Mataco) }\end{array}$ & Katun & $\begin{array}{l}\text { Hiasannya satu warna yang tersebar (cadangan } \\
\text { tersendiri yang bagus). }\end{array}$ \\
\hline Argentina & $\begin{array}{l}\text { Calilegua } \\
\text { (Quichua } \\
\text { Mestizos) }\end{array}$ & Katun & - \\
\hline
\end{tabular}

\section{Teknik Dasar Tie-dye}

Pada dasarnya keteknikan dalam tiedye dibagi menjadi dua, yaitu teknik tie (pengikatan) dan teknik dye (pewarnaan), dengan uraian sebagai berikut.

\section{Teknik Tie (ikat)}

Ambil bagian kain yang akan menjadi pusat dari motif. Ikat bagian bawahnya dengan tali plastik (raffia) atau benang sintetis. Lakukan dua atau tiga ikatan di bawahnya atau sesuai rancangan yang diinginkan. Lanjutkan dengan pewarnaan kemudian ikatan dibuka. Dari teknik ini bisa dihasilkan motif lingkaran pada pusatnya yang dikelilingi beberapa lingkaran luar yang lebih besar dengan bias-bias yang tidak beraturan pada area pengikatan. 


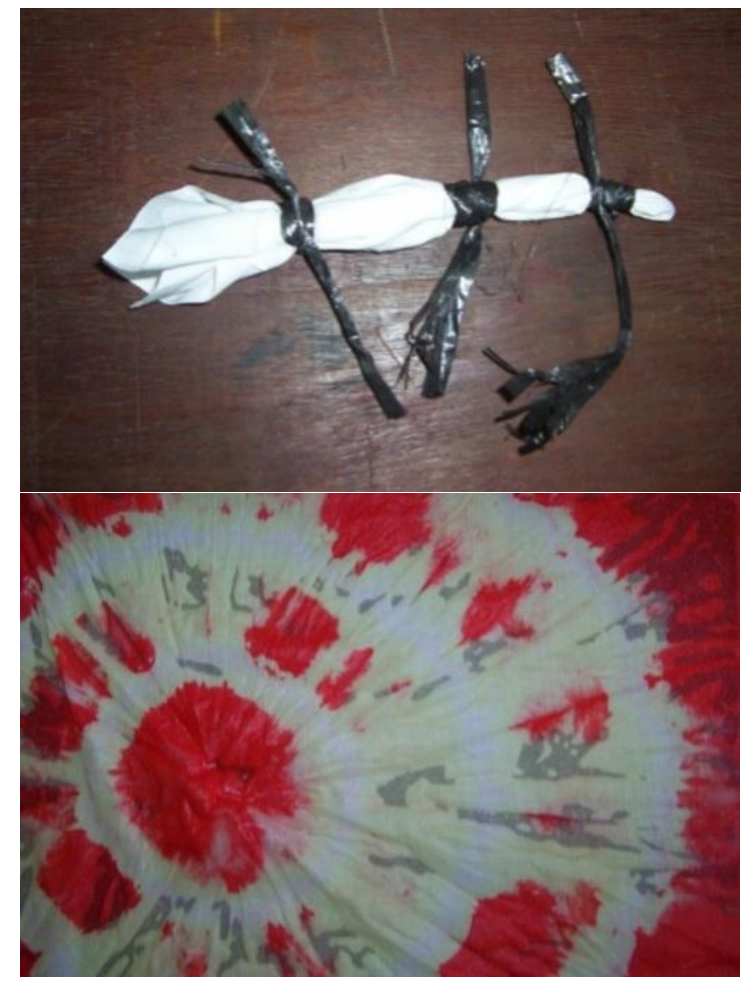

Gambar 1. Teknik Tie (ikat)

\section{Teknik Fold (simpul)}

Kain dilipat atau digulung terlebih dahulu, kemudian diikat pada beberapa bagian penampangnya menggunakan tali plastik (raffia) atau benang sintetis. Lakukan proses pewarnaan kemudian ikatan dibuka. Teknik ini dapat menghasilkan motif garis vertikal sesuai karakter pengikatan, bisa berupa garis lurus maupun berkelok dinamis dengan bias-bias pada bagian outline-nya.

\section{Teknik Knot (kancing)}

Teknik knot (kancing) pada prinsipnya merupakan teknik mengikat dengan menggunakan kain itu sendiri dengan cara kain dipilin kemudian diikat dengan kuat. Selanjutnya kain diwarna dan ikatan tadi dilepas. Motif yang dihasilkan adalah berupa lingkaran yang terpusat dengan bagian luar mengelilinginya dengan bias-bias menyebar seperti sinar matahari yang membentuk keseluruhan motif.

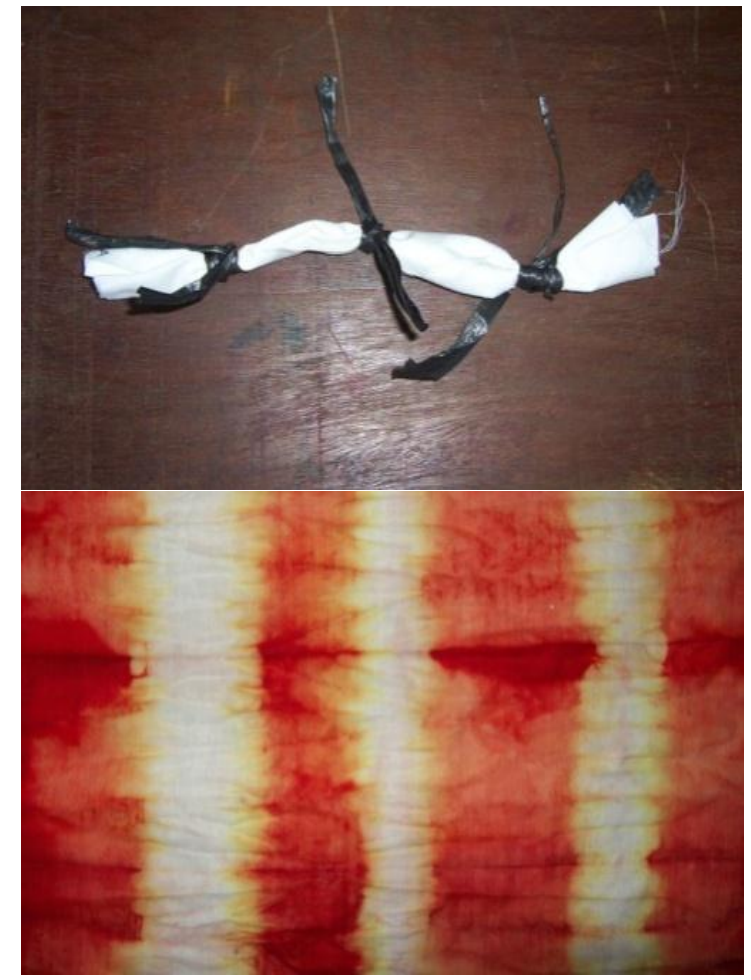

Gambar 2. Teknik Fold (simpul)

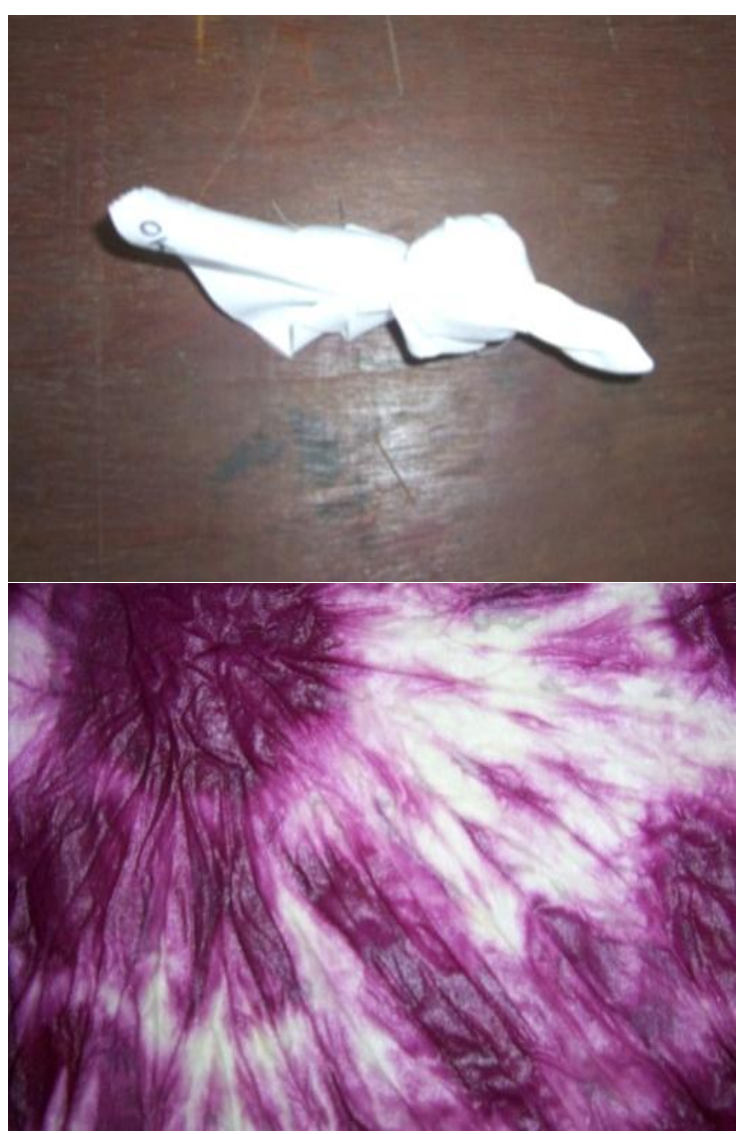

Gambar 3. Teknik knot (kancing) 


\section{Teknik Marbling (marmer)}

Teknik marbling (marmer) dilakukan dengan cara kain dikerut atau dikumpulkan secara bertahap dari bagian tengah yang disatukan dengan bagian pinggirnya, hingga kain terbentuk menjadi sebuah gumpalan. Dari bentuk gumpalan ini kemudian kain diikat atau dibelit sedemikian rupa saling menyilang satu sama lain hingga membentuk seperti sebuah bola. Setelah diwarna, ikatan dibuka dan terlihat hasilnya sebuah motif seperti permukaan marmer dengan gelap terang yang menyebar tak beraturan membentuk kesan tiga dimensional.

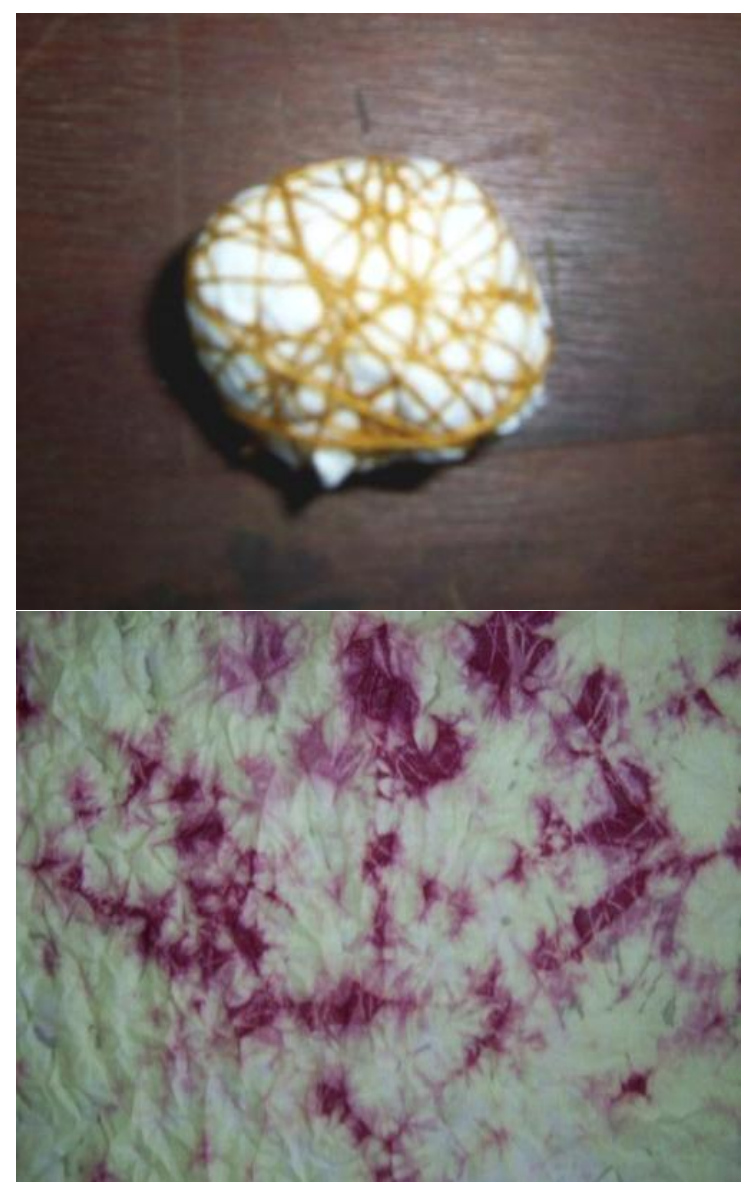

Gambar 4. Teknik Marbling (marmer)

\section{Teknik Stitch (jahit)}

Terlebih dahulu kita buat garis sebagai motif atau lajur jahitan di atas kain, kemudian lakukan penjahitan tangan dengan teknik jelujur. Jarak jahitan disesuaikan dengan ukuran motif yang diinginkan (biasanya berjarak 0,5 $-1 \mathrm{~cm}$ antartitik jahitan). Setiap kira-kira $10 \mathrm{~cm}$ jahitan, kain dikerutkan secara bertahap untuk menjaga kerapatan dan ketahanan terhadap proses pewarnaan, namun benang harus dijaga agar jangan sampai terputus. Setelah selesai, benang ditarik dan disimpul kuat-kuat agar tidak terkena perembesan warna. Lakukan proses pewarnaan dan benang dilepas secara perlahan. Hasil dari teknik ini adalah berupa garis yang tersusun seperti butiran-butiran padi sesuai lajur jahitan yang telah dibuat sebelumnya.

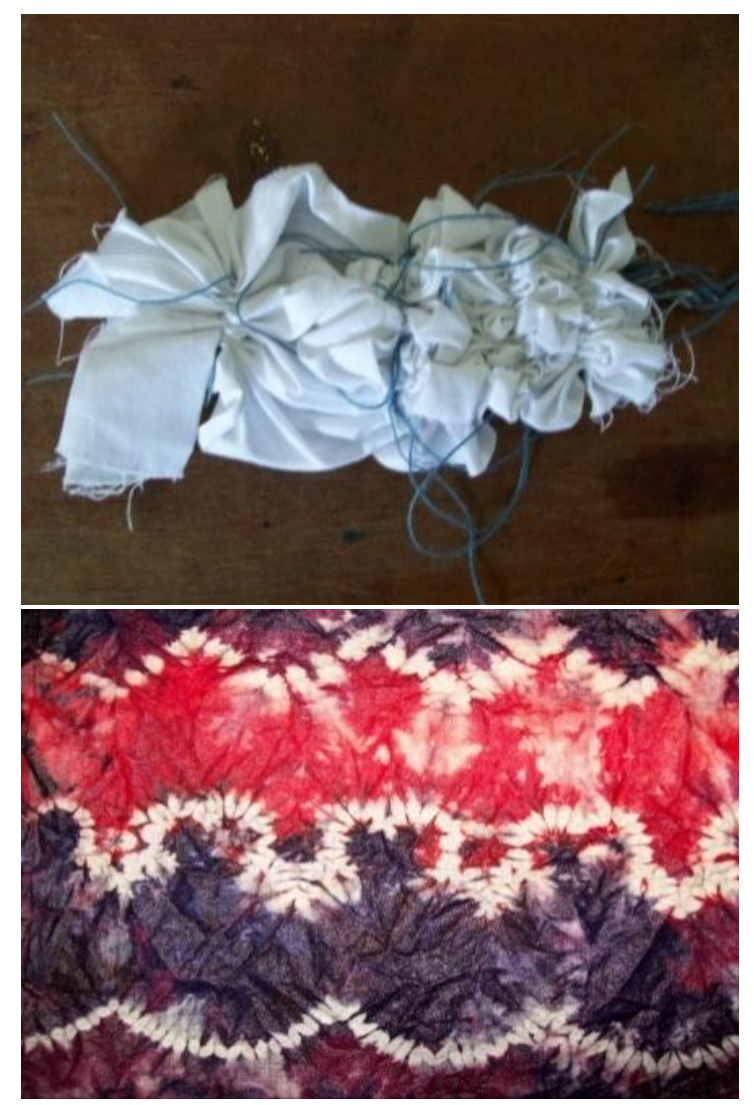

Gambar 5. Teknik Stitch (jahit)

\section{Teknik Roll (gulung)}

Teknik roll (gulung) ini hampir sama dengan teknik fold (simpul), hanya perbedaannya kain digulung pada sebuah pipa (pralon). Pada salah satu bagian ujung kain diikat dengan tali plastik (raffia) atau benang 
sintetis. Kain terlebih dahulu dibasahi, digulung, dan dikerut secara bertahap menuju ujung yang terikat. Setelah kain dikerutkan secara sempurna, pada bagian ujung lainnya juga diikat untuk menjaga hasil kerutan agar tetap kencang dan tidak bergeser pada waktu proses pewarnaan. Lakukan proses pewarnaan, ikatan dibuka, dan lepaskan gulungan kain dari pipa (pralon). Teknik ini dapat menghasilkan motif seperti aliran air di tepian sungai yang halus lembut dengan biasbiasnya yang juga luwes, kadang-kadang bisa berbentuk seperti nyala api yang sedang berkobar.

\section{Teknik Pleat (lipat)}

Teknik pleat (lipat) merupakan pelbagai metode melipat kain yang dilakukan atau dibentuk sedemikian rupa untuk menghasilkan motif dari efek lipatan tersebut. Sebagai contoh di bawah ini adalah kain dilipat-lipat sedemikian rupa hingga membentuk segitiga. Setelah selesai pelipatan, kain kemudian diwarna pada ketiga bagian sudutnya saja (kain tidak dicelupkan semuanya ke dalam warna). Setelah kain diberi warna pada ketiga bagian ujungnya tersebut, lipatan dibuka. Teknik ini dapat menghasilkan motif berupa pola yang berulang seperti motif ceplok pada batik.

\section{Teknik Press (tekan)}

Teknik press (tekan) merupakan pengembangan dari teknik pleat (lipat), yaitu kain dilipat terlebih dahulu kemudian dilakukan proses penjepitan. Alat untuk menjepit biasanya digunakan dua bilah kayu untuk mendapatkan area penekanan, yang pada kedua bagian ujungnya diikat kuat-kuat, bisa dengan tali atau karet gelang. Penjepit berfungsi menahan warna pada waktu proses pewarnaan. Hasilnya adalah berupa motif pengulangan (repetisi) seperti motif ceplok pada batik, sesuai bentuk dari area penjepitan yang tidak terkena rembesan warna.

\section{Teknik Kerut}

Teknik kerut sama halnya dengan teknik pleat (lipat), namun tidak melalui proses pengikatan. Kain terlebih dahulu dibasahi kemudian hanya dikerutkan sesuai keinginan atau sesuai rancangan. Pada contoh dapat dilihat bahwa kain dikerut dengan pola kerutan memusat pada satu titik di tengah dengan cara diputar. Pewarnaannya digunakan teknik spray (semprot), siram (tuang), atau tabur. Teknik ini dapat menghasilkan motif seperti pusaran air.

Untuk tahap dye (pewarnaan) dikenal
beberapa keteknikan. Yang lazim
dipergunakan adalah teknik dye (celup) dan
colet (dikuaskan). Namun pada tahap
perkembangan selanjutnya dapat juga
diterapkan dan divariasikan dengan berbagai
macam teknik pewarnaan yang lain, seperti
spray (semprot), siram (tuang), dan tabur,
ataupun kombinasi dari berbagai teknik
pewarnaan tersebut.

Untuk tahap dye (pewarnaan) dikenal beberapa keteknikan. Yang lazim dipergunakan adalah teknik dye (celup) dan colet (dikuaskan). Namun pada tahap perkembangan selanjutnya dapat juga diterapkan dan divariasikan dengan berbagai macam teknik pewarnaan yang lain, seperti spray (semprot), siram (tuang), dan tabur, pewarnaan tersebut. 

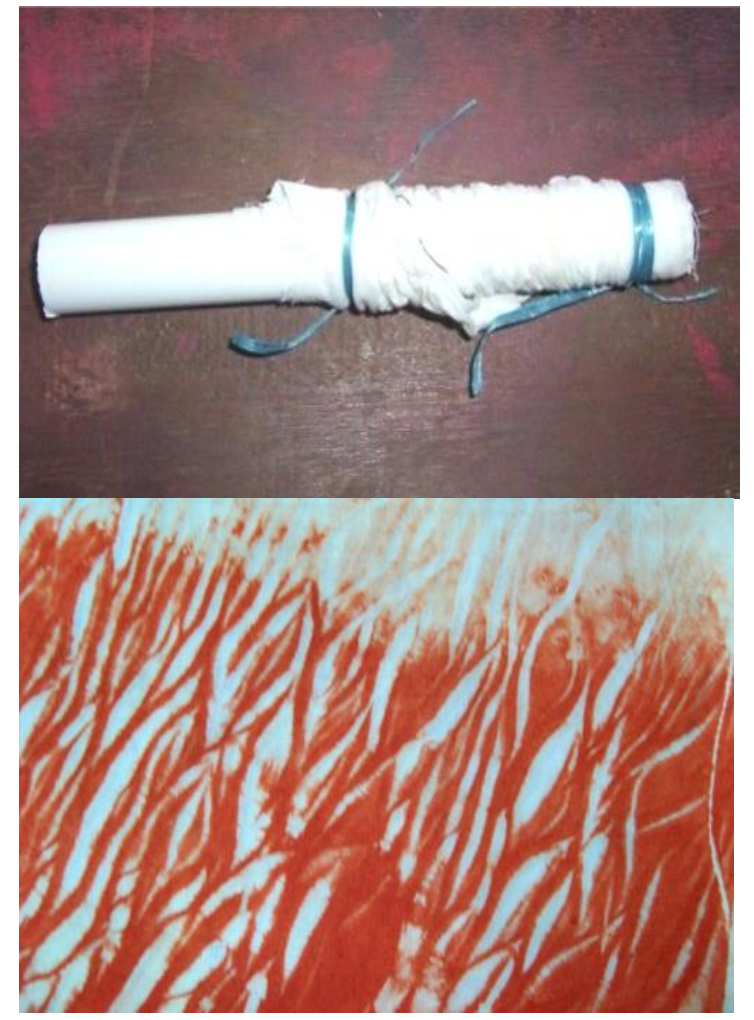

Gambar 6. Teknik Roll (gulung)

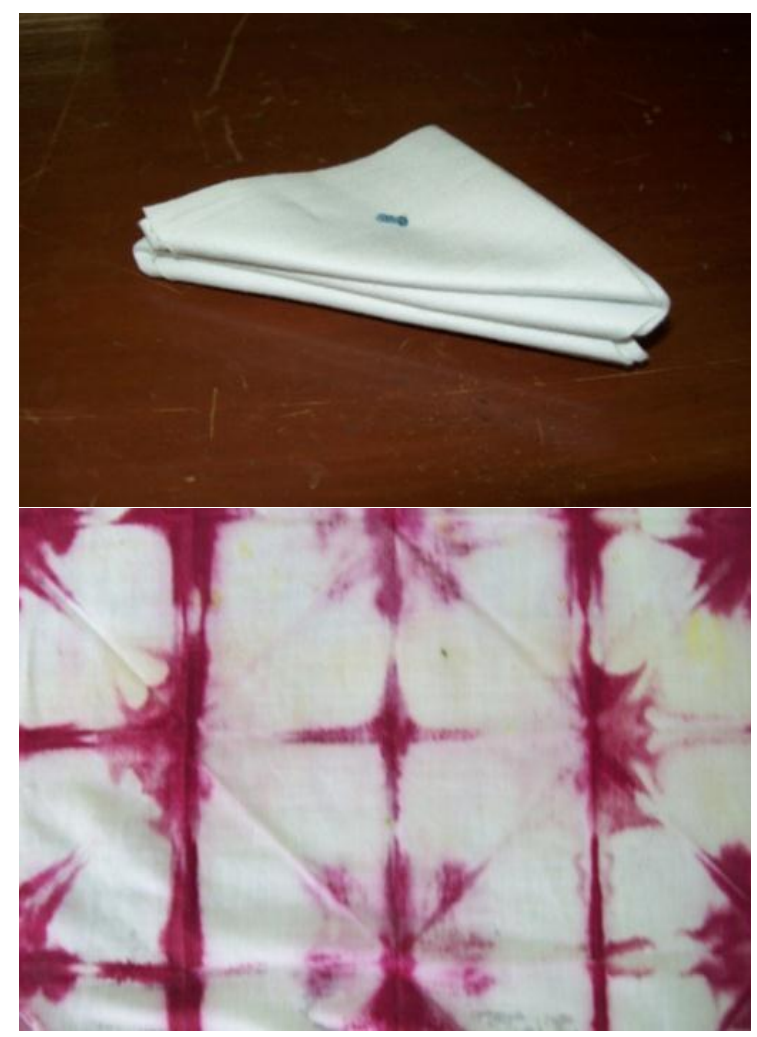

Gambar 7. Teknik Pleat (lipat)

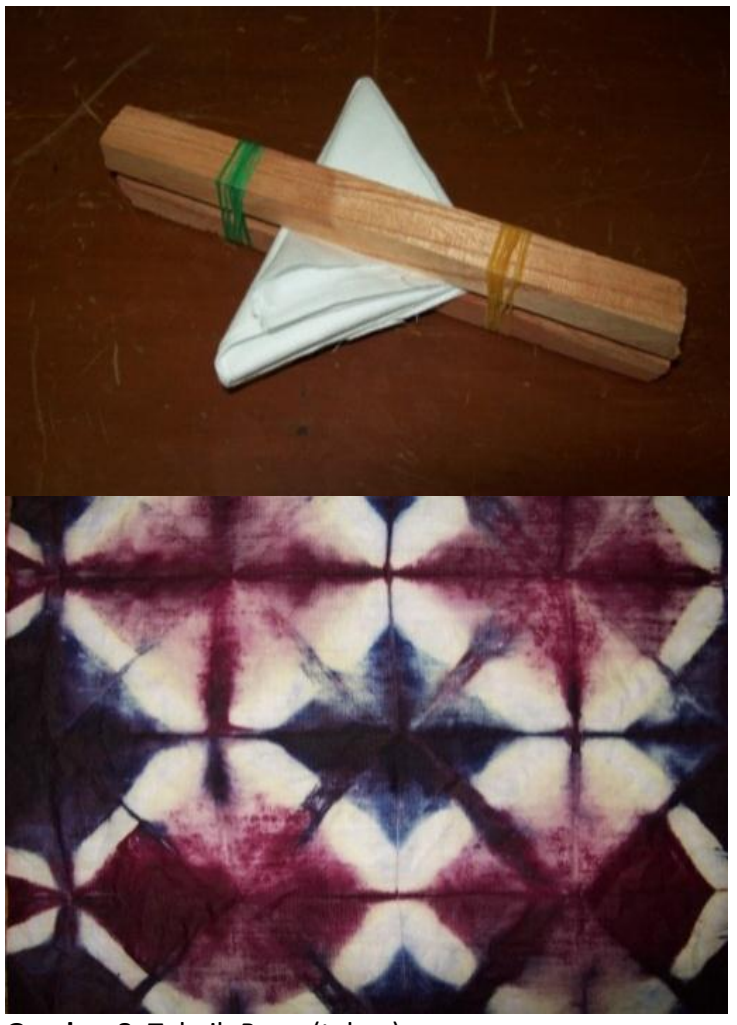

Gambar 8. Teknik Press (tekan)

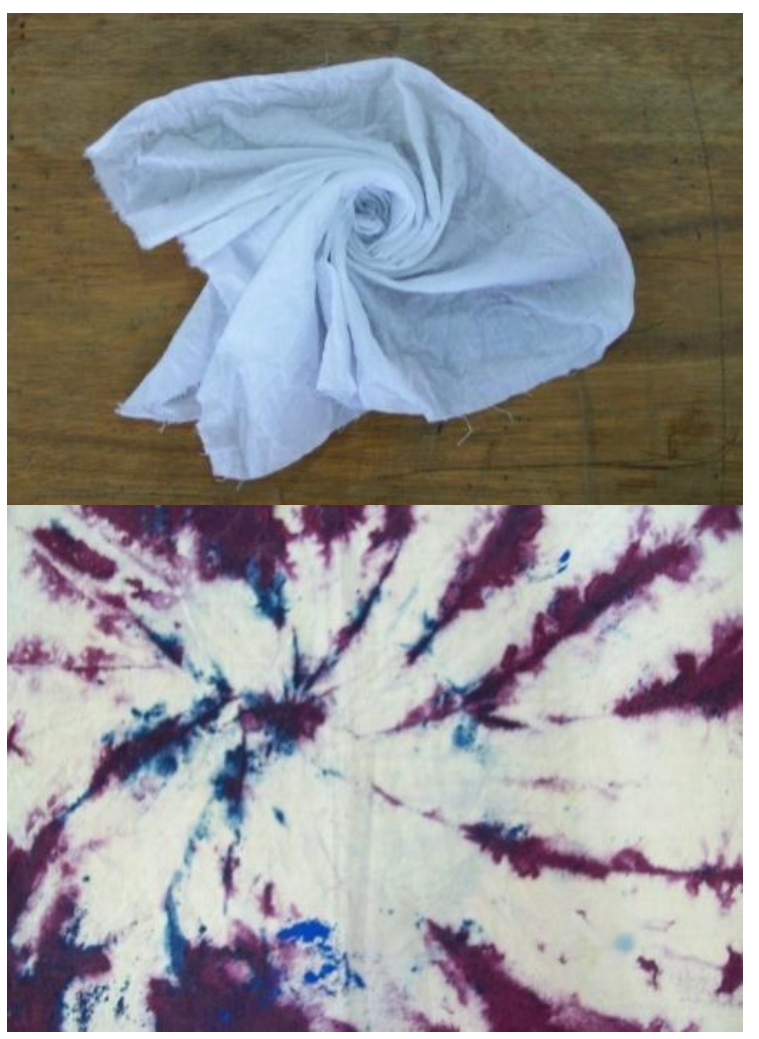

Gambar 9. Teknik Kerut 

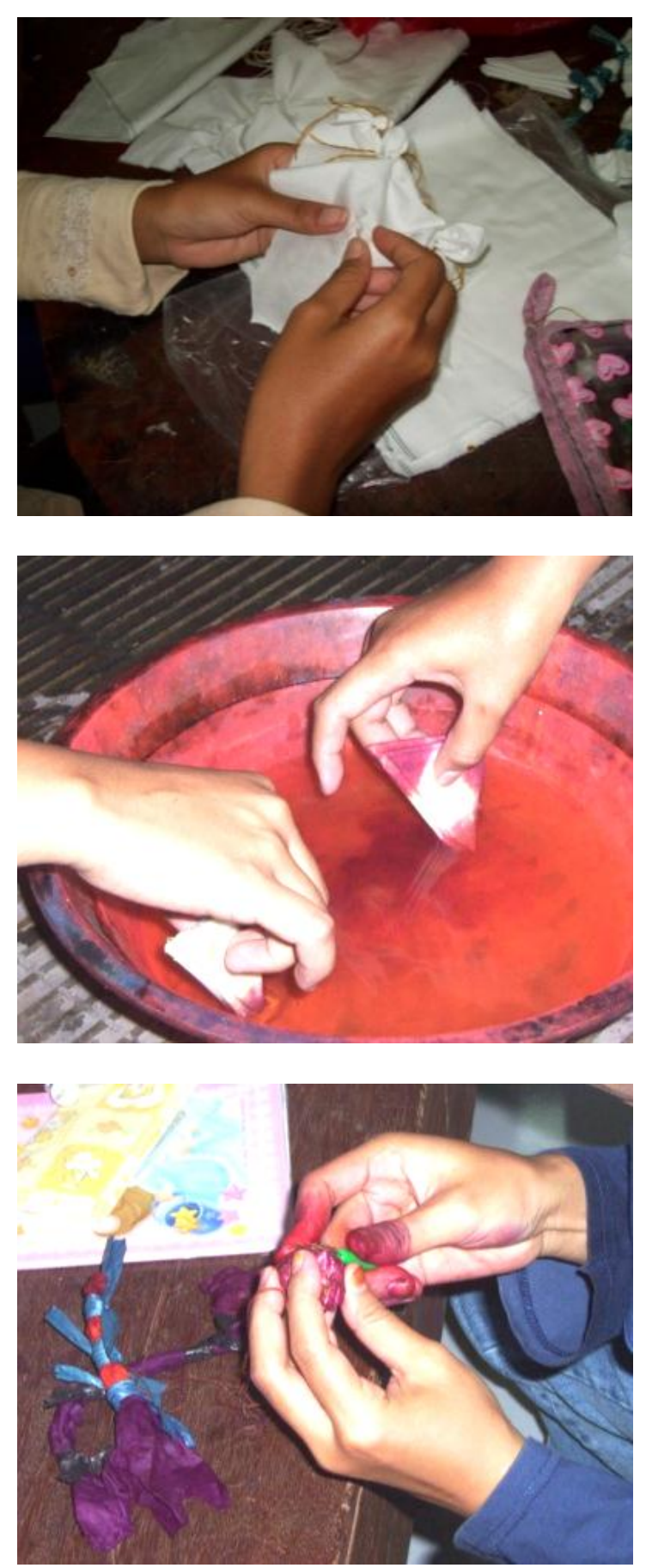

Gambar 10. Proses Tie (pengikatan), Dye (pewarnaan), dan Pembukaan Ikatan

Berbagai keteknikan dasar dalam tie-dye yang disajikan di atas, dapat terus dikembangkan dan digali, baik dari aspek keteknikan, alat, maupun bahan secara tidak terbatas. Kombinasi dari berbagai macam keteknikan juga lazim dilakukan guna mencapai atau menciptakan berbagai motif atau efek-efek baru yang menarik dan artistik secara visual. Semuanya sangat tergantung dari eksplorasi, rasa estetis, serta kreativitas dari masingmasing pembuatnya.

\section{Berbagai Produk Tie-dye}

Pada prinsipnya, semua produk yang dapat dihasilkan dengan keteknikan tie-dye, tidak ada bedanya dengan produk-produk yang berbahan dasar tekstil pada umumnya. Produk-produk yang dapat dihasilkan meliputi produk busana (fashion) dan perlengkapannya, perlengkapan interior, cenderamata, berbagai macam produk kerajinan, termasuk di dalamnya adalah sebagai media pengungkapan ekspresi seni rupa murni (fine art).

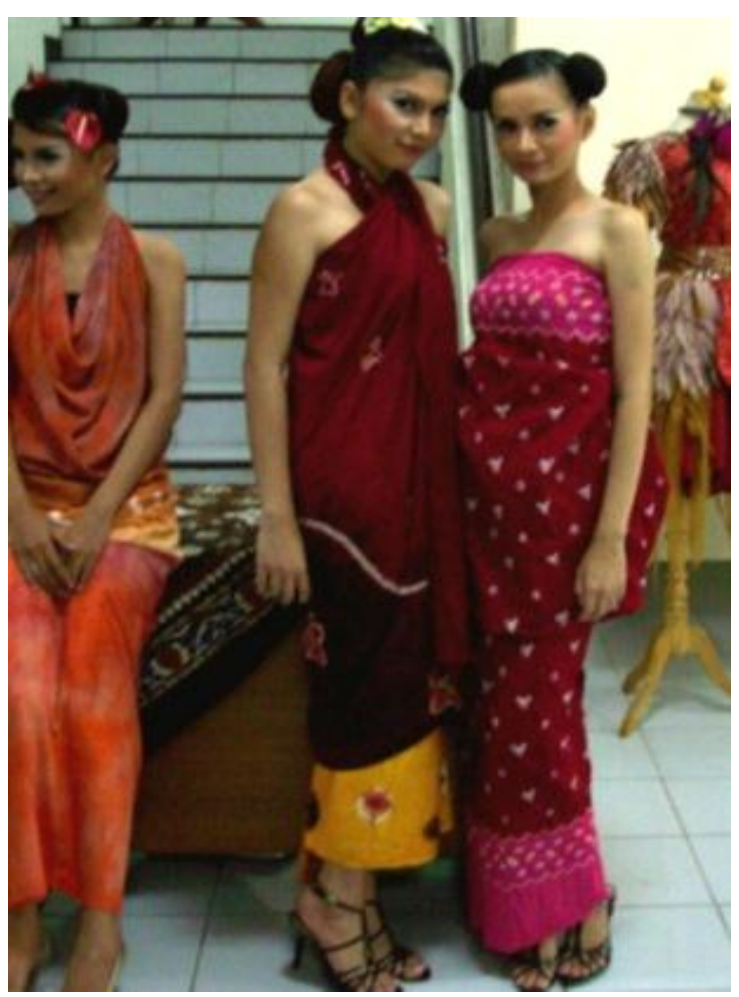

Gambar 11. Produk Busana (fashion) dan Perlengkapan Busana 


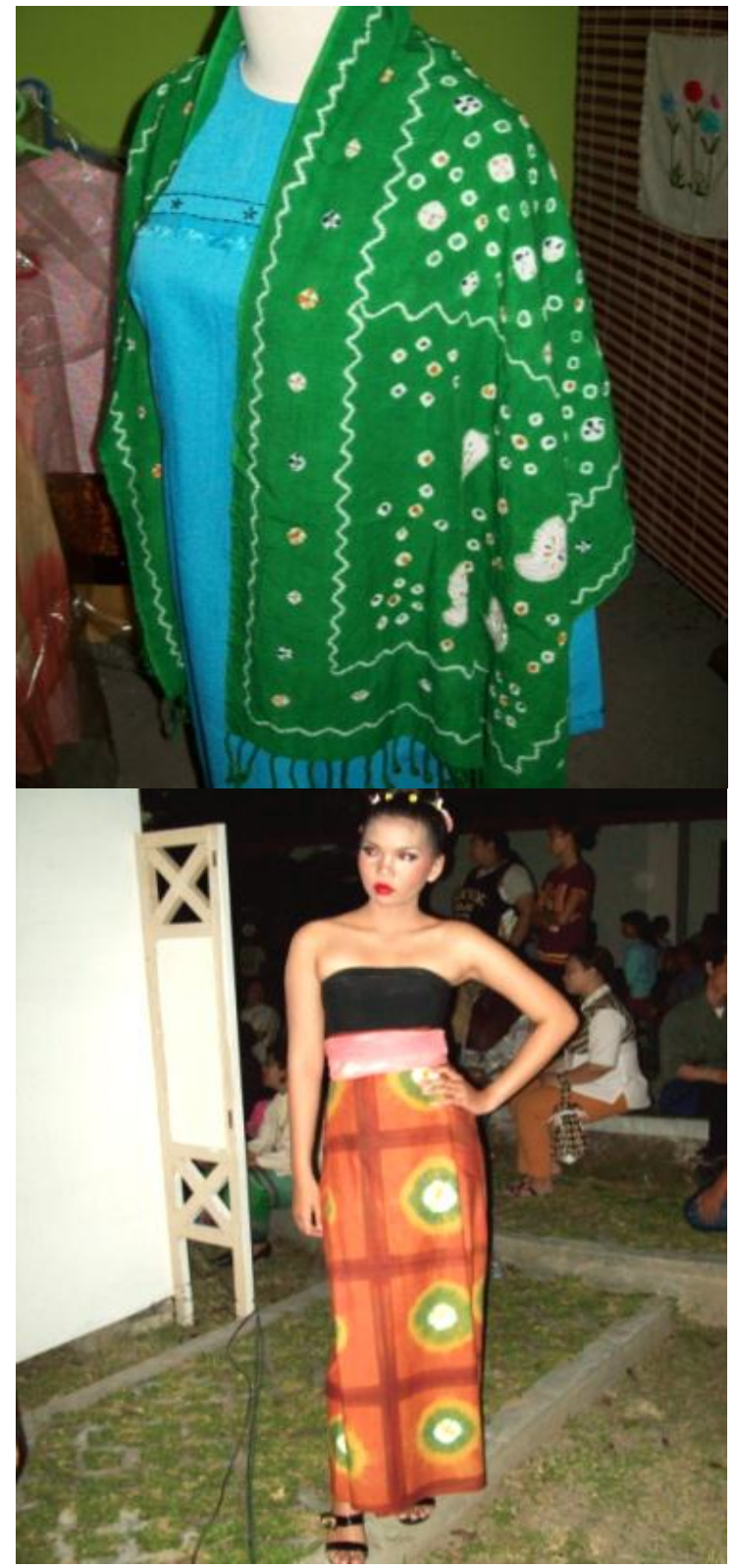

Gambar 12. Produk Busana (fashion) dan Perlengkapan Busana

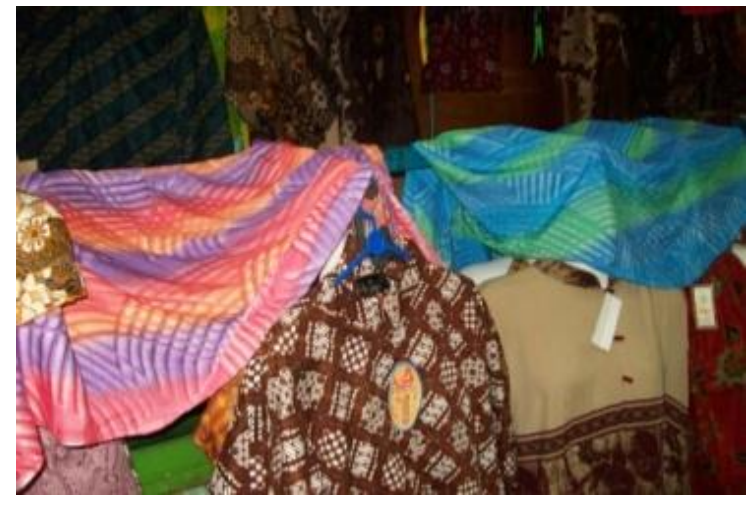

Gambar 13. Perlengkapan Interior (taplak meja)

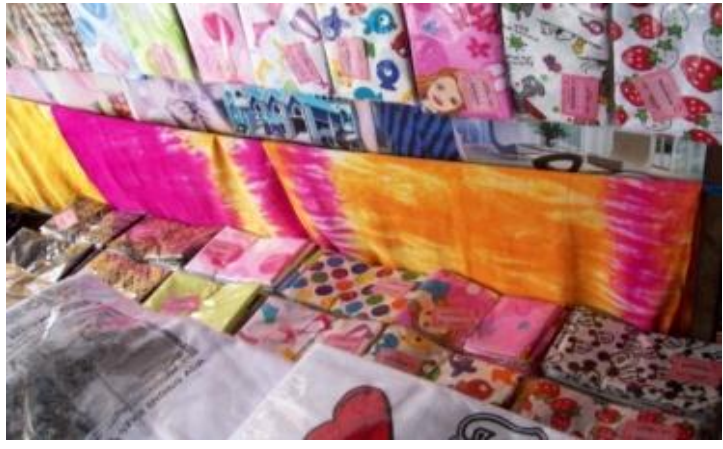

Gambar 14. Produk Cenderamata (scarf)

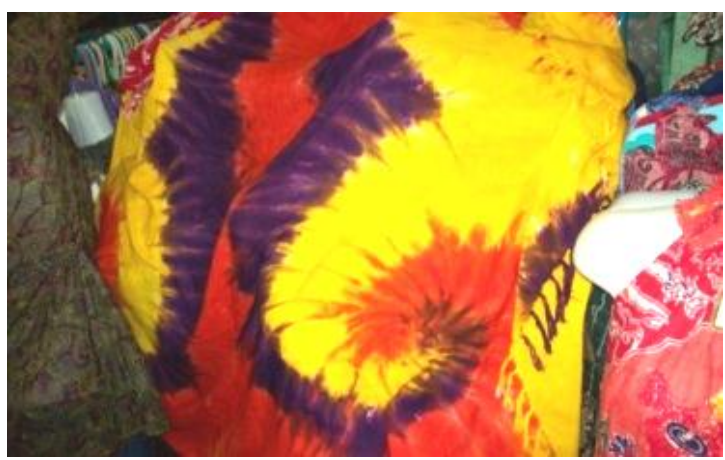

Gambar 15. Kain Pantai

\section{Penutup}

Kebutuhan primer manusia akan bahan sandang, tampaknya sangat menunjang kepopuleran tie-dye sebagai salah satu media dalam pembuatan motif di atas kain. Adanya saling interaksi antardaerah penghasil yang satu dengan daerah penghasil lainnya, menjadikannya sebagai sebuah hasil budaya yang multikultural dan dinamis dalam proses perkembangannya. Tekniknya yang relatif mudah untuk dipelajari, didukung dengan alat dan bahan yang murah dan mudah untuk didapatkan menjadi faktor pendukung utama hingga dikenal secara meluas dan menjadikannya sebagai sebuah hasil budaya yang membumi dan cukup signifikan. 


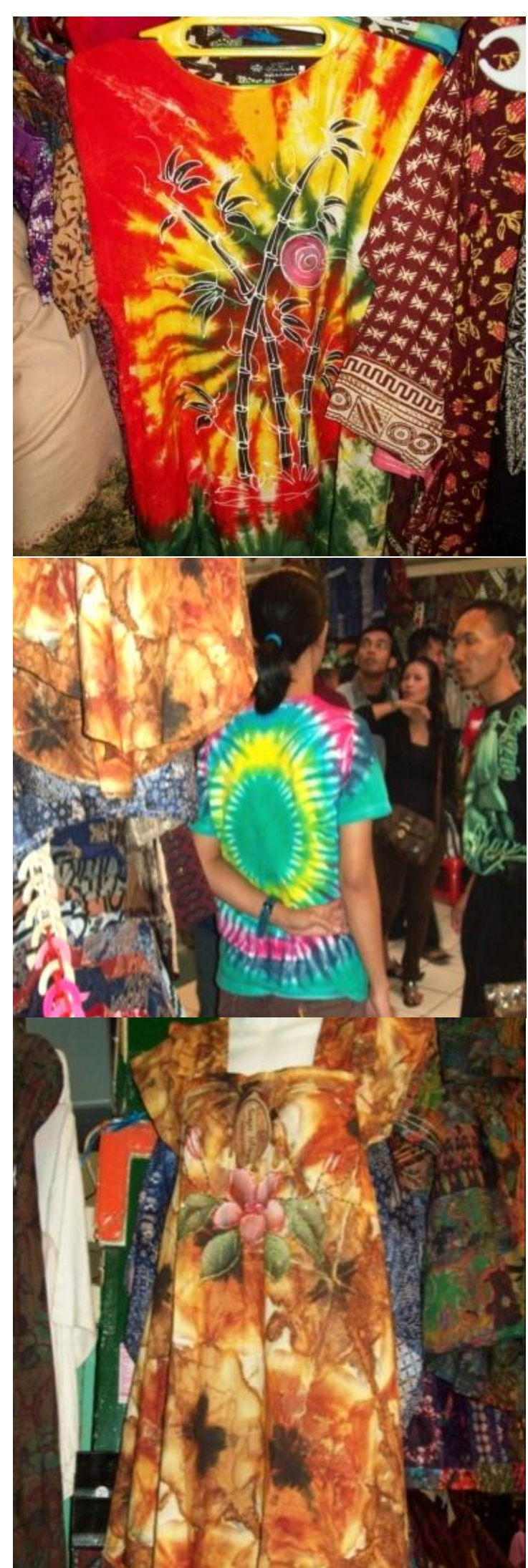

Gambar 16. Produk busana dikombinasikan dengan batik, diterapkan pada kaos,

dan dikombinasikan dengan aplikasi payet atau manikmanik
Unik, menarik, instan, simpel, dan mengundang rasa penasaran. Demikian kesan yang langsung bisa ditangkap dalam berkarya melalui media tie-dye ini, hingga mampu memacu gairah untuk terus bereksperimen. Hal ini juga menjadi salah satu faktor pendorong pengembangan dari keteknikan ini. Dari beberapa teknik dasar dalam tie-dye, berbagai keteknikannya dapat dikombinasikan serta dapat dieksplorasi, baik dari aspek teknik pengikatan maupun teknik pewarnaan, termasuk dari segi pengembangan serta penggunaan alat dan bahan.

Di samping lazim dipergunakan sebagai bahan dasar seperti halnya pada produk-produk tekstil pada umumnya, tie-dye juga sangat potensial sebagai media untuk pengungkapan rasa estetis dalam berkarya seni rupa murni secara ekspresif. Hal ini tidak terlepas dari beragam motif yang dapat ditemui dan dihasilkan dengan berbagai variasinya, dengan efek yang bernilai artistik tinggi, seringkali tak terduga dapat muncul atau dimunculkan begitu saja, bahkan dapat terwujud tanpa unsur kesengajaan di dalamnya.

Tie-dye terus berkembang pesat seiring kemajuan dan semangat zaman yang telah dilaluinya. Berbagai jenis dan bentuk karya tie-dye yang inovatif, akan terus memotivasi terciptanya berbagai macam hasil kreasi dan rancangan baru yang akan selalu dapat kita jumpai. Demikian ulasan kali ini, mudah-mudahan yang sedikit dan bersahaja ini minimal dapat memberikan tambahan wawasan, rangsangan, serta inspirasi dalam berkarya kriya tekstil. 


\section{Daftar Pustaka}

Anderson, Fatidjah. 1974. Tie-Dyeing and Batik. London: Octopus Books.

Djoemena, Nian S. 1990. Batik dan Mitra: Batik and Its Kind. Jakarta: Djambatan.

"Ikat Celup dalam Komodifikasi" dalam Kompas no. 300 tahun ke-44, PT.

Joanifer, Gibbs. 1974. Batik Unlimited. London: Watson-Guptill Publications, New York Pitman Publishing.

Kompas Media Nusantara, Jakarta, Minggu 3 Mei 2009.

Keller, Ila. 1971. Batik: The Art and Craft. Tokyo: Charles E. Tuttle Company Publishers Rutland, Vermont.

Linton, George E. 1954. The Modern Textile Dictionary. New York: Duell, Sloan, and Pearce Little, Brown and Company Boston-Toronto.

Robinson, Stuart. 1969. A History of Dyed Textiles. London: Studio Vista.
Wada, Yoshiko Iwamoto, Kellogg Rice, Mary, and Barton, Jane. 1999. Shibori: The Inventive Art of Japanese Shaped Resist Dyeing: Tradition Techniques Inovation. Tokyo: Kodansha International Ltd.

Warming, Wanda and Gaworski, Michael. The World of Indonesia Textiles. Tokyo, New York, and San Fransisco: Kodansha International Ltd.

Widodo, Suryo Tri. 1998. "Kriya Tekstil Tie-Dye di ARIMBI Fashion Design \& Production Exclusive Tie \& Dye". Skripsi sebagai syarat untuk mencapai derajat Sarjana S1 pada Program Studi Kriya Seni, Jurusan Kriya, Fakultas Seni Rupa, Institut Seni Indonesia Yogyakarta.

\section{Narasumber}

Sumarmi Arimbi (52 th.), perancang dan pengusaha tie-dye tinggal di Yogyakarta. 